\title{
シンポジウム
}

\section{2. がん診療の現状}

司会 国立がんセンター

阿部 薰

司会 名古屋市立大学第二内科 上田龍三

今日のがん診療の進展を支えているのは， 日々の地道な診療の積み重和に加えて, 近代分 子生物学に基づく基礎生物学の進歩, 医学工学 とくに医学電子工学の進歩, さらに医療情報 ネットワークの整備に依るところが大きい。こ れらの進歩はがん診療において，より早期の発 見, 再発の予知に慗がり，集学的治療を可能と し，がんの5年生存率や治瘉率向上に着実に貢 献している。しかし，本邦におけるがん死亡は 年間 27 万人にぼ死因の第一位を占め，それ は来世紀半ばまでその座を譲らないことが予想 されている。

本シンポジウムではがん診療領域で非常に注 目されている以下の話題を紹介し，次世紀のが ん診療の在り方を展望してみたい，1）医療電 子工学の飛躍的進歩がもたらしつつあるがん画 像診断の臨床へのインパクト（国立がんセ，森 山紀之博士)。2）近年の基礎生物学の進展は, がんが遺伝子異常の積み重ねにより，発症・進 展・憎悪することを明らかにした。このことが 遺伝子診断として，がんの早期発見，治療効果 のモニタリング，がんの個性診断にいかに利用
され始めているか（名市大・内科，上田龍三博 士).3）細胞の特性を規定する分子をがん診療 の標的とする分子標的治療の意義と今後の展開 (九大・内科，中野修治博士)，4）腫瘍に特異 的に反応するCTLクローンの樹立とその認識 抗原ペプチドの同定という新しい免疫応答の流 れを利用した腫瘍免疫療法が次期のがん治療の 真の担い手と成りうるか（三重大・内科，珠玩 洋博士)。5）現在のがん治療は患者にとって過 酷なことが少なくない，さらに，多くのがん患 者は痛み，呼吸困難など，がんによる色々な症 状で苦しんでいる．患者の家族のQOLを踏ま えたがん告知，および緩和療法（阪大・人間工 学, 柏木哲夫博士).6）最新の医学情報やがん の診断・治療・予防等に関する情報ネットワー クの整備の有用性と将来性（国立がんセ，水島 洋博士)。本シンポジウムを通じて，がん診療 の現状をまとめながら，21世紀へのがん診療の 正しい方向性について, 本学会員の皆様ととも に考える機会への一助となればと考えておりま す.（非会員の森山，柏木，水島先生のご協力 に深謝致します) 


\section{1）がん画像診断の進歩}

\section{国立がんセンター東病院 森山紀之}

がんの画像診断法を大きく分けるとコン ピュー夕導入以前の画像診断機器を用いた診断 方法と画像診断機器にコンピュータシステムが 導入された後の画像診断方法とがある. 前者に おいては画像診断検査方法手技および詳細な読 影技術の隻歩が挙げられるが，近年における進 歩としては僅かなものである。一方，後者につ いては超音波検査, $\mathrm{CT}, \mathrm{MRI}$ な゙の断層検查の 他に従来の検查方法をコンピュータと連動させ ることによって，より診断能の向上した電子内 視鏡やコンピューティドラジオフラフィがあ る。超音波検查, CT, MRIにおいては機器自体 の性能の向上が現在も続いておう，これに伴う 種々の検查方法, 造影剤の開発が行われている。 超音波検查に扔いてはカラードプラ法の精度向 上に伴い，超音波検查において弱点とされてい た実質臓器がんの質的診断能が向上した，CT
におういてはへリカルCTの開発に伴い, 腹部実 質臟器を動脈相, 門脈相, 静脈相の時相別に撮 影することが可能となり, がんの診断能が飛躍 的に向上した。

肺がんに対するへリカルCT検査では, 従来 の胸部単純X線検查では発見不能であった早期 の肺がんが数多く発見されるようになり，ヘリ カルCTを用いた肺がん検㟝も開始されるよう になった，MRIにおいては，新しい撮像方法や 造影郕の開発に伴い, 診断能は向上し, 脳・神 経領域・骨盤腔内・婦人科領域では最も優れた 画像検查方法となっている，核医学画像におい ては癌細胞の代謝面から見た画像診断方法とし てのPETが登場し, 存在診断の他に細胞のviabilityに対する診断が進歩した。へリカルCT やMRIの連続した画像情報を用いた診断では， 客観的な三次元画像が得られるようになった。

\section{2）がんの遺伝子診断}

\section{名古屋术立大学第二内科 上田龍三}

がん遺伝子，がん抑制遺伝子の発見に基づく この20年来の基礎研究の進展から，がんは正常 細胞における遺伝子異常の積み重齐から生じる ことが明らかにされた，その遺伝子異常には染 色体転座に上る融合遺伝子形成户遺伝子過剩発 現, 遺伝子久失, 点突然変異, メチル化異常等 が知られており, 現在それらの異常の多くは遺 伝子検索により検出可能となっている.

がんの遗伝子診断は検体採集が簡便で, 染色 体解析が早くから利用できた白血病, 墨性りン パ腫において最も進歩している．免疫グロブリ
ン, あるいはT細胞受容体遺伝子を用いたサザ ン解析は病理学的には腫瘍性か否かの判別がで きなかった MALT，AILDといったリンバ増 殖病変が単クローン性腫瘍性疾患であることを 明らかにした。また，成人T細胞性白血病やEB ウイルス関連腫瘍のようなウイルス発がんの診 断も実現されている。染色体転座の解析は急性 白血病でのFAB分類, 昰性りンパ腫でのREAL 分類といった細胞形態学的診断が, 特異的な遗 伝子異常と呼応することを明らかとしてきてい る.急性前骨髅性白血病のレチノイン酸による 
分化誘導療法は分子機序に基づく臨床応用の代 表例である。また急性白血病における $\mathrm{ABL}$ 融合遺伝子形成やマントル層リンパ腫で のBCL1/cyclin D1遗伝子の過剩発現は決定的 な子後不良因子であり，早期骨髄移植の必要性 が指摘されている。さらに再発予知の点から FISH法やPCR法を用いた高感度の微少残存病 変（minimal residual disease, MRD）の検出法 が開発され，濾胞性りンパ腫におけるBCL2遺 伝子では骨髄移植のin vitroでのpurging効果と
再発阻止のための指標として有用である。

造血器腫癔に限らずいくつかの固形がんでも p53遺伝子に代表されるがん抑制遺伝子の遺伝 子変巽や多剂耐性遺伝子であるMDR1遺伝子の 発現，最近注目されているテロメア短小化，テ ロメラーゼ活性化はがんの悪性度の判定に用い られつつある。このようにがんの遺伝子診断は 21世紀へのがんの遭伝子診療（遺伝子を用いた 診断と治療）の基盤的な成果をあげている.

\section{3）がん化学療法の新しい分子標的}

\section{九州大学第一内科 中野修治}

最近の癌細胞の生物学的研究のめざましい進 展とともに，癌細胞の特性を規定する分子の機 能を修飾することによって癌細胞の脱癌化，薬 棛耐性克服，浸潤・転移抑制，腫瘍血管新生の 抑制，アポトーシス誘導などで癌を治療しよう という，いわゆる“分子標的治療”の概念が生 まれてきた。これらは殺細胞效果を狙った従来 の化学療法と全く異なる治療アプローチであ り，癌との共存も視野に入れた今後期待される 治療の一つといえる．癌化学療法の分野での新 しい分子標的として，（1）シグナル伝達機構， 受容体，（2）薬剤耐性機構，（3）癌遺伝子 癌 抑制遺伝子，(4) 血管新生関連分子，（5）浸潤 ・転移関連分子, (6) テロメラーゼやアポトー シス機構，などがあり，その治療実施法として は，（1）分子機能阻害郕，（2）遺伝子治療，（3） アンチセンス治療，(4) サイトカイン治療など が考えられる．現在臨床的に応用されている慢 性骨髄性白血病に対するインターフェロンや前
骨髄性白血病に対するレチノイドも分子標的治 療の一つである，我々は遗伝子治療も視野に入 れ，癌の増殖，浸潤，薬剤耐性などに関与する シグナル伝達分子を標的にした研究を行ってい る. Rasは多くの癌で発現しておう, Farnesyl transferase阻害剂はRas機能を抑制し，増殖や 浸潤能を抑制する.SrcやerbB-2癌遺伝子は大 腸癌, 乳癌, 肺癌に異常が認められるチロシン キナーゼで，浸潤・転移をおこし，薬殽耐性も 誘導する.SrcやerbB-2の機能をチロシンキ ナーゼ阻害剤で抑制すると，脱癌化が抢こり耐 性も克服される. Ras下流のRacは細胞の遊走 能に関連のある分子で，この機能を变異抑制分 子 (Dominant negative Rac) で阻害すると癌 の浸潤を抑制する。本シンポジウムでは，この ような我々の知見も含めて，癌化学療法におけ 万分子標的治療の意義と治療戦略について考察 する. 


\title{
4）がん免疫療法の可能性
}

\author{
三重大学第二内科 珠现 洋
}

悪性腫瘍に対する免疫的治療に大きな期待が 寄せられつつある．担㿋生体の免疫機能の増強 をはかることによって悪性腫瘍を治療するとい う考え方は決して新しいものではない，事実多 くの悪性腫瘍に対して様々な免疫的治療が行わ れてきた。しかしながら，費やされてきた時間 と努力の多さにもかかわらず，今日迄免疫治療 法は，悪性腫瘍に対する治療の一角を確立する 迄には到っていない。

最近の, 生体内におけるT細胞免疫応答の分 子機構の研究成果，およびそれを取り入れた， 覀性腫瘍細胞に対する免疫の理解と解析は，癌 の免疫治療の新しい科学的基礎を造りつつあ る.とりわけ，過去数年間にわたり各種腫瘍系 で腫湯細胞に特異的に反応するCTLクローン を樹立し，腫瘍細胞より作成したcDNAライブ
ラリー中の抗原支配遗伝子を単離同定する試み や，腫瘍細胞のMHCクラス I 結合性ペプチド を抽出し，その中よりCTLクローンと反応す るペプチドを同定することが進められてきた。 これらのアプローチとは別に，腫湯細胞に限局 して発現される遺伝子由来のペプチドが腫瘍抗 原ぺプチドになり得るかを検証することも試み られている，候補遺伝子としては，腫湯細胞で 発現の元進している癌遗伝子や点然然変異や染 色体転座を起こし得る癌遺伝子や癌抑制遺伝子 等が挙げられる。

今回のシンポジウムでは、これらの腫瘍に対 する免疫応答に関する最近の進歩と動向につい て御紹介し、これらの新しい知見に基づいて各 種腎性腫瘍に対する免疫的治療法をどの様に開 発し得るかを考えてみたい。

\section{5）がん告知と緩和医療}

\section{大阪大学人間科学部 柏木哲夫}

がんの早期発見と集学的治療により，近年が んの 5 年生存率はかなり高くなってきた。一方， 相変わらずがんは日本人の死因の第一位であ り, 平成 8 年度の統計によると，年間 27 万人か がんで死亡しており，これは全死亡数の30.2\% にあたる。

がん告知の問題は治癒不可能な進行がんや末 期がんに関して特に重要になる。どのような治 療を選択するかを決めるのは患者である，その ためには本当のことを知る必要がある．1996年 の毎日新聞の調查によると, 不治なのであれば， 延命中心の医療よりも緩和医療を選ぶと答えた
人が90\%であった。一方，不治であっても知ら せてほしい人が $66 \%$ ，不治であれば知らせてほ しくない人が31\%であった，積極的な治療をす るか，緩和医療を選択するかを決めるためには 患者が自分の病名，病状を知っている必要があ る。治療の進歩とともに，緩和医療も進歩して いる。

WHOのPalliative Careの定義によると，「Palliative Careとは治痛を目的にした治療に反応 しなくなった患者に対する積極的で全人的なケ アであり，痛みや他の症状のコントロール，精 神的，社会的，霊的な問題のケアを優先する。 
Palliative Careの目標は患者と家族のQOLを高 めることである. Palliative Careは聅㭧の初期 段階においても，癌治療の過程においても適用 される」とある。要約すると，癌医療のあらゆ る過程に適用される䅡極的な (active)，全人 的な（total），QOLを重視した，舁者と家族に
対するケアということになる．また㾰治療の過 程における適用という点からすると，単に末期 想者だけをその対象とするのではない，ホスピ スやターミナルケアに従事してきた者と，癌治 療に従事してきた者とが協力できる場が緩和医 療であると言える。

\section{6）がん情報ネットワーク}

\section{国仙がんセンター砳筧所 水島 洋}

国立がんセンターでは，がんの誩療および治 療レベルの向上と格差の是正をめざして，情報 委員会が中心となり，平成 5 年度から「がん診 療総合支援システム」の一環としてスーパーコ ンピュータの導入とともにがん情報ネットワー クを構築し，全国のがんセンターとの連携をは かっている.

このネットワークは1994年に30Km離れた東 京都中央区築地の国立がんセンター (中央) と， 千葉県柏市の国立がんセンター（東）との間を $6 \mathrm{Mbps}$ の光ファイバー専用線で接続したこと に始まった．1994年12月からは国立の地方がん センターの接続が開始され, 現在では国立およ び県立の地方がんセンターが合計11施設接続さ れている．通常のテレビ会議システムと高精細 画像をもちいたシステムであり，どこからでも 発信することができる。

毎週木曜夕方のメディカルカンファレンスで は，1つのテーマに沿った発表を各施設が持ち 回りでおこなっている。このほかにも画像を中 心としたカンファレンス，病理，骨軟部腫瘍な どの他, 看護婦, 放射線技師, 薬剤師, 臨床検 查技師などのカンファランスも毎月開かれてお
り，参加者は97年 1 月から10月末まででのべ 1 万人を超えている。また一部施設だけではある が，火曜の早朝には内科のカンファランスを毎 週開いている。

このネットワークでは，高精細画像による遠 隔カンファレンスとともにインターネットの接 続も行っている。これを利用して国立がんセン ターが提供する「最新がん情報サービス」をは じめ,インターネット上にある世界中の多数の 有用な最新の医学情報を取得することが可能に なっている。

また，海外からの演者の講演を多地点に流す ばかりでなく，海外との迋隔医療実験も試みて いる. 米国Georgetown大学やArmed Forces Institute of Pathologyとの間での遠隔病理診断を はじめ, 米国Duke大学との高精細画像を用い た遠隔医療寒験などを行っている.

このように、これからのがん診療にとっては 情報をいかに使うかがより大切になってくる が，国立がんセンター情報委員会の取組が全国 のがん診療の進歩につながっていくことを期待 する。 